\title{
The Concept of Balance at Sekati Ririg Gending in Tejakula, Buleleng Regency
}

\author{
I Ketut Aditya Putra ${ }^{\bowtie}$, Hendra Santosa, I Komang Sudirga \\ Institut Seni Indonesia Denpasar, Indonesia
}

Submitted: July 23, 2020. Revised: September 19, 2020. Accepted: November 4, 2020

\begin{abstract}
This study aims to determine the concept of balance found in playing techniques, tempo, and dynamics (ngumbang-ngisep) at Sekati Ririg Cenik gending in Tejakula, Buleleng Regency. The research is focused on the presentation using the barungan of Gong Kebyar gamelan, because at the time of handling the beginning observation, it was presented to accompany religious ceremonies at Pura Maksan Tejakula. This research is a qualitative study using several data collection techniques; observation, interviews, documentation, and literature. The approach used is a musicological approach using aesthetic theory. The results obtained from this study are the concept of dualism balance in terms of some of the forming elements in it, such as playing techniques on instruments pemade, kantilan, trompong, reyong, and ceng-ceng kopyak. These are some of the instruments that use the polos-sangsih system in their playing. Playing Technigue usually play parallel to the tempo, while playing technique sangsih is still playing against the tempo. Furthermore, the concept of balance at tempo can be seen from the speed with which gending Sekati Ririg Cenik is presented. The presentation begins with a slow tempo, then after several repetitions of the gending the tempo slowly changes to faster until it reaches the end of the gending, and the tempo is again set to slow. Likewise with the concept of dynamic balance which can be viewed from the loudness of the musical presentation. Setting the tempo and dynamics is intended to achieve balance and will not cause boredom in the presentation. These three things can be implemented in the Gong Kebyar gamelan instrument which is used as a medium in presenting Sekati Ririg Cenik gending by the community in Tejakula Village.
\end{abstract}

Keywords: concept; galance; gending; Sekati Ririg Cenik

How to Cite: Putra, I. K. A., Santosa, H., \& Sudirga, I. K. (2020). The Concept of Balance at Sekati Ririg Gending in Tejakula, Buleleng Regency. Harmonia: Journal of Arts Research And Education, 20(2), 183-194

\section{INTRODUCTION}

The Balinese people believe in a dualism dimension as a concept of life balance or what is known as rwa bhineda. Dualism comes from the Latin word duo (two), which means teaching that states that reality consists of two different and contradictory substances. (Sutrisno, 2014). The word rwa bhineda in Bali's lives is a con- cept of difference or contradiction that is always one and inseparable from one another. Thus, this concept is very much embedded in human life in the universe. Rwa bhineda actually explains how God created the universe in a paired condition but in contradiction. For example, the creation of men and women, black and white, and so on. This is written by Ida Pandita Dukuh Celagi Dhaksa Dharma Kriti (2019) in his

\footnotetext{
${ }^{\square}$ Corresponding author:

E-mail: hendra@isi-dps.ac.id
} 
book "Bhaerawa Adalah Jalanku" states: rwa bhineda in his concept, couples with different characters must be side by side, not mutually exclusive.

For life to run in harmony, Rwa Bhineda teaches that two opposites must balance each other. In their desire to do something, the Balinese desire to stick to the concept of balance as the basis for carrying out all their actions. This has been written in the lontar Prakempa that the balance of human life in the dimension of duality is to believe in the existence of two terrible forces, such as good and bad, day and night, man and woman, and, at times, and others (Bandem, 1986). The duality dimension can be parallel to the concept of rwa bhineda which is believed by Hindus in Bali, who have differences or resistance but still cause balance and harmony.

In general, Balinese gamelan also has the concept of dualism balance. As stated by (Sugiartha, 2015) that two-dimensional balance is a characteristic of Balinese gamelan, because it has the meaning of togetherness and mutual need. As stated by Sugiartha (2015), a two-dimensional balance is a characteristic of Balinese gamelan, because it means togetherness and needs each other. The terms male and female are also usually used in Balinese gamelan, such as the female drum (wadon) and male drum (lanang) instruments. (Utomo, 2006). Besides, the round gong instrument is also present in Balinese gamelan. This reflects the concept of a balance of dualism in Balinese gamelan, one of which is in the gamelan barungan Gong Kebyar.

Gamelan Gong Kebyar has several instruments arranged using a two-dimensional concept from a physical point of view, such as the resulting tone being lower and the resulting tone being higher. Apart from being seen from a physical perspective, the Gamelan Gong Kebyar uses a two-dimensional concept that can be seen in terms of musicality, such as using the polos-sangsih system in its playing techniques.

Gong Kebyar is one of the many types of gamelan instruments/groups that have developed very rapidly in Bali at present. The mutual influence between Gong Kebyar and other gamelan is due to the fertility of the life of Gong Kebyar in Bali. In accordance with the statement of Aryasa (1985) that the gamelan Gong Kebyar is often used to present music from other gamelan, such as the gamelan Semar Pegulingan, Bebarongan, and the music from the gamelan Gong Gede. Thus, Gong Kebyar as an identity is often seen as the result of active community efforts to preserve and introduce it to the world. Through Gong Kebyar Balinese people get their identity (Rismandika, 2018).

Gending in the musical world has become a common term and is also very popular. The term gending is usually used in the designation for musical composition. Gending is a song or contains a sense of having a form and composition (Aryasa, 1985). Refer to a definition of gending Sekati Ririg Cenik, according to Pande Gede Mustika, if it is seen from Sekati, it should have the root word "katih" which in Balinese terms means one or single.

In music, the word "one" can be viewed from the song pattern and structure of the colotomic instrument. In one gongan gending, there is only one kempul and kempli stroke and the trompong instrument play pattern, which uses the play pattern innocently following the melody's flow without any progression of the gending. Then, the word "ririg cenik" itself is also a Balinese term that can be divided into two syllables, namely ririg, which is almost the same as mejejer and mebaris which means sequential or rows. Meanwhile, the word cenik in Balinese terms means small. Meanwhile, the word cenik in Balinese terms means small. The Sekati Ririg Cenik gending is musically one of the pieces which as a whole has a single form and structure characterized by one kempur punch, kempli in one gongan and has a series of melodies that lead to higher notes or into smaller octaves (interview Monday 24 September 2018). Gending Sekati Ririg Cenik is classified as a guardian art or a religious performance of ceremonial gending, that's becau- 
se the dish only functions to accompany the procession of presenting religious ritual offerings at the time of the Dewa Yadnya ceremony. The yadnya god ceremony (i) is worship or offering as a form of devotion before God and all its manifestations. The ceremony is determined based on sasih (a ceremony held once a year) and based on pawukon forecast count (Putra, 2004).

Based on the above phenomenon, the researcher is interested in making this object as research material to find out how the concept of dualism balance found in the Sekati Ririg Cenik music in the Tejakula, Buleleng Regency. In accordance with the results of preliminary observations that have been made, the Gamelan Gong Kebyar is used to present Sekati Ririg Cenik gending by the community in Tejakula and is also used to show music from the Gong Gede gamelan such as tabuh telu, tabuh pat, and gilak when performing piodalan at the temple Maksan of Tejakula Village.

This research is very important to do because apart from efforts to preserve it, no one has ever researched this case before. So the researchers hope that this paper can provide information to everyone related to the Sekati Ririg Cenik gending in Tejakula, Buleleng Regency. The research focuses more on the concept of balance of dualism dimensions viewed from several elements, such as playing techniques in the polos-sangsih system, the concept of tempo balance, and dynamics in the Sekati Ririg Cenik gending presentation. So that in writing, it is discussed in depth about these three things.

\section{METHODS}

This study used the descriptive qualitative method. Sugiyono (2015) states that the qualitative research method is a method that examines the condition of natural objects, where the researcher is the key instrument. The data collection technique is carried out by triangulation (combined), the data analysis is inductive/qualitative, and the research results emphasize the meaning of more than generalization.
This research's implementation related to data sources can be grouped into two, namely primary data and secondary data sources. Furthermore, techniques in collecting data can be done by several methods, including observation techniques, interviews, documentation questionnaires, and a combination of the four (Sugiyono, 2009). Therefore, from Sugiyono's statement, this study's data collection techniques used several techniques, including observation, interviews, documentation, and literature. The observation technique was carried out by observing Sekati Ririg Cenik gending directly at the time of the Dewa Yadnya ceremony held at Pura Maksan, Tejakula Village.

The interview technique is carried out by interviewing several people influential on the object of research, such as artist figures in the village concerned, musicians involved in the performance of Sekati Ririg Cenik, the head of the gong group, and several residents of the Tejakula Traditional Village. The interview technique is carried out by interviewing several people who are influential on the object of research, such as artist figures in the village concerned, actors or musicians involved in the Sekati Ririg Cenik gending presentation, the head of Sekaa gong group, as well as several residents in the Tejakula Traditional Village. Interviews were conducted in-depth by asking questions that had been prepared in accordance with the research needs. The documentation technique is done by taking pictures or videos when the people of Tejakula present Sekati Ririg Cenik gending. Researchers do this by collecting books, journals, and similar research results to understand and add broader insights into the literature technique. In addition, researchers also compare the data obtained in the field with the results of interviews and interviews; researchers compare the results of interviews with main informants and other informants. The approach used in this study is a musicological approach, which is an approach to read problems in musical, scientific fields, including the form of music, the textual music, and the 
musical context.

\section{RESULTS AND DISCUSSION}

\section{Sekati Ririg Cenik Gending}

The implementation of religious ceremonies carried out by the community in the Tejakula Traditional Village is inseparable from social interaction and art performances, both dance and music, that are sacred or entertaining. As social and cultural creatures, humans certainly interact with each other, the environment, and with God. Social interaction, in this case, is in expressing art in social life. It is an expression of human culture that is always present as a personal expression and an expression of community groups based on the culture. Individuals and community groups can use or use it as a means of social interaction (Wadiyo, 2006). Social interaction here is an expression of art in social life because art is an expression of human culture that is always present as a personal expression. It also an expression of community groups based on the culture it refers to, from which individuals and community groups can use or exploit as a means of social interaction (Wadiyo, 2006). Therefore, it can be said that art has a role as a means of social interaction as an example in the gending, which is presented when carrying out social activities for religious ceremonies in Tejakula Traditional Village.

The people in Tejakula Traditional Village generally carry out the piodalan ceremony for three days. In connection with Sekati's repertoire presentation, the local community usually performs five Sekati repertoires, one of which is Sekati Ririg Cenik gending. Suppose the community carries out the piodalan ceremony at Pura Kahyangan Tiga. In that case, the gamelan barungan used is Gong Gede gamelan; it is because the temple's existence is classified as the main level in the local village area. Meanwhile, when local people carry out the piodalan ceremony at Pura Maksan, the presentation of the Sekati Ririg Cenik gending is, of course, using the Gong Kebyar gamelan. Given this temple's existence, apart from having a small area, this temple is classified as an intermediate level in Tejakula Traditional Village area (interview with Gede Santara, 11 July 2020). So that there is a clear difference in terms of presentation using two different gamelan sets, and it all depends on where the local community holds the religious ceremony. Likewise related to Sekati's gending offerings, generally, it can only be found on the second day when carrying out Ngebekin ceremony (the peak of the piodalan ceremony) and the third day at the Ngelebarang ceremony (the end of the piodalan ceremony celebration). This has indeed become an agreement of the local community to continue the tradition passed down long ago.

The presence of Sekati Ririg Cenik gending in Tejakula Traditional Village contextually appears when the community is carrying out religious ceremonies that are similar to the existence of the Gamelan Sekaten in the three Keraton, namely the Surakarta, Yogyakarta, and Cirebon Palace. Contextually, Gamelan Sekaten is also used in the traditional ritual ceremonies of each Keraton. (Utami, 2011), states that the existence of Gamelan Sekaten, one of which is in the Great Mosque of Surakarta, is a concept that is closely related to sacredness and part of the Sekaten Ritual in the sacredness of Gerebeg Maulud. This explanation shows that there are a relationship and an important role between musical offerings and the implementation of religious rituals aimed at God.

\section{The Concept of Balance on playing tech- nique of Sekati Ririg Cenik Gending \\ The playing technique or gagebug} also has its concept or way when playing a gamelan known as polos-sangsih. Polos and sangsih system will move if combined and cause a mix of sounds called ubitubitan, moving up and down or vice versa and filling in empty beats and making interlocking sounds (Bandem, 2013). The technique in gamelan in Bali is known as ubit-ubitan, kotekan or cecandetan. Dibia (2017) explaining textures is one way 
to build complex but rich sound textures. When playing the kotekan, two or three gamelan players play or have a tight interaction. Each player plays intricate rhythmic patterns or strokes to perform the main melody. While the word cecandetan itself comes from the word "candet-candet", the word means mutually muttering. Reproach is meant to respond to a sound with another sound so that it creates a rhythm when the gamelan is played.

Generally, each instrument in gamelan Gong Kebyar has ubit-ubitan, kotekan, and cecandetan technique used in the polossangsih playing system. Polos-sangsih system explained by Dibia (2017) that playing polos strike is often called negtegin (from the word tegteg, the balinesse language means strong) because of this strike move along with kajar strike. Sangsih strike is also called nimpalin (from the words timpal in Balinesse language means Friend) because of this beat's function as a friend or a couple from polos. Based on the above understanding, some instruments of gamelan Gong Kebyar that are used to present gending Sekati Riring Cenik also uses playing technique with polos-sangsih system as it is mentioned above. Some of them apply the oncang-oncangan, norot and twist check five techniques, namely the pemade and kantil instruments, reyong, ceng-ceng kopyak, and trompong (Putra, 2019). Each of these instruments produces a strand of tones according to their musical needs so that the process can create a complementary balance.

Pemade and kantil instruments are instruments in the Gong Kebyar gamelan, which both have a pelawah shape made of wood and a bronze blade; it's just that the size of the kantilan instrument is smaller than the pemade instrument. In general, the function of pemade and kantil is to work on music with a variety of twists/ties, including oncang-oncangan and norot (Sukerta, 2001). Pemade and kantil instruments in the Sekati Ririg Cenik gending presentation, using a plain-sangsih system with the types of norot and oncang-oncangan playing techniques. Before moving on to definition of norot, it is necessary to know about understanding the meaning of nyocol. Nyocol is meant to be a playing technique in a medium tempo, which is done by hitting the same note (with two strokes in one beat). The term nyocol is taken from the Balinese language, namely cocolan (from the word cocol) which means one lump.

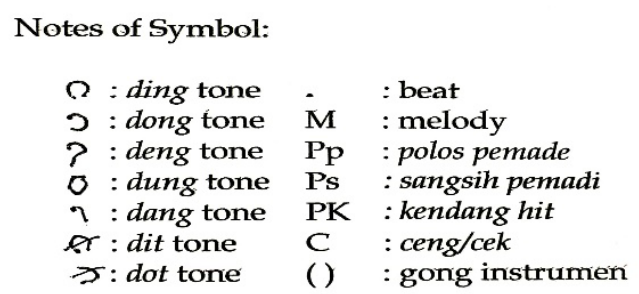

Figure 1. Description of Notation Symbols (Doc. Aditya Putra,2020)

From the definition of nyocol, it can be seen that the norot strike technique is a compacted nyocol punch. Norot can be done by closing the first note or leaving both notes open (Dibia, 2017). While the type of oncang-oncangan stroke is the name of a stroke pattern that uses strokes that alternate by hitting two different tones interspersed with one tone. The results of these strokes can be intertwined in one direction, so that the notes that are heard are always sequential. Meanwhile, the type of oncang-oncangan stroke is the name of a stroke pattern that uses alternating strokes by hitting two different notes interspersed with one note. This stroke can usually be done in the fast and responsive part of the repertoire (Mustika, 1996).

Apart from the meaning of oncangoncangan in the context of music, the word oncang/ngoncang can also be found in a tradition that still exists today. This tradition is still maintained in many places, such as in Buleleng and Tabanan areas. In this case, ngoncang can be interpreted as a customary activity carried out in groups, one group usually consisting of five or six people. Women only did Ngoncang because it was believed that only women pound rice in ancient times. The tradition of ngoncang is done by playing a rice pounding tool or kentungan (Listiani, 2014). Each 
player has a different rhythm pattern and the strokes are taken alternately regarding how to play it. Besides being used in the implementation of the ngoncang tradition, the oncang-oncangan playing technique is also used in the musical concept of the Sekati Ririg Cenik gending in the Tejakula Traditional Village, Buleleng Regency.

The oncang-oncangan technique in the Sekati Ririg Cenik gending is also performed by alternating between polos and sangsih strokes, every musician who plays this technique naturally adjusts the melody that has been composed. So that these patterns of play are intertwined complement each other.

Before arriving at an explanation of the playing techniques in Sekati Ririg Cenik gending, it would be nice to understand some of the symbolic descriptions used in the notation. The goal is none other than to make it easier to read examples of notation in this paper;

\begin{tabular}{|c|c|c|c|}
\hline NI & $\ldots l$ & $\ldots n$ & $\ldots 1$ \\
\hline$P$ & .0 .1 & .2 .0 & 0.0 \\
\hline & $\therefore 9$ & 1.?. & $\therefore$ \\
\hline
\end{tabular}

Figure 2. Example of oncang-oncangan playing technique notation on a pemade instrument

(Doc. Aditya Putra, 2020)

Furthermore, below, we can describe examples of oncang-oncangan and norot playing techniques in Sekati Ririg Cenik gending through the notation of playing the pemade instrument in the gamelan Gong Kebyar. The following is an example of the oncang-oncangan playing technique in Sekati Ririg Cenik gending.

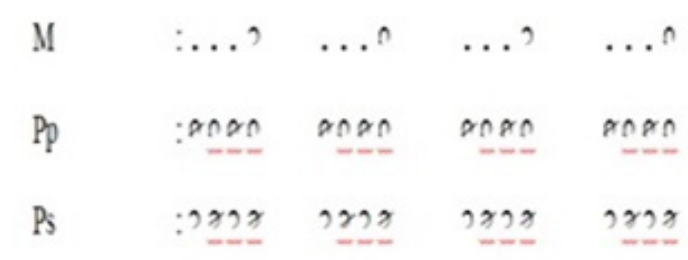

Figure 3. Examples of the notation of the norot playing technique on the pemade instrument (Doc. Aditya Putra, 2020)
From the example of the polos-sangsih pemade playing technique notation on the oncang-oncangan stroke type, pemade polos $(\mathrm{Pp})$ instrument has a playing technique by hitting two different notes in one beat and line with the melody beat of the gending. While the beat of the Pemade Sangsih (Ps) instrument is played by hitting two different notes in one beat, the strokes are opposite to the beat of the melody which aims to complete the empty space of pemade polos playing. These two game systems are complementary intertwined from each note produce on each beat. So, it is very clear that there is a parallel or opposite playing process between polos and sangsih strokes that cause a balance to arise. Likewise, with the norot playing technique, the following is an example of the norot playing technique notation in Sekati Ririg Cenik gending.

From Figure 3 of the norot playing technique above, you can see the process of balance between polos and sangsih strokes that are produced through a complementary tune in each beat. The norot stroke on a polos pemade instrument plays the same two notes in one beat. It is also noteworthy that in the norot polos strokes above, there are a number of notes played with the blade closed, which is indicated by a ding note that is crossed out with a sound "dit." Likewise in the norot strokes on the pemade sangsih (Ps) instrument, the technique of playing it is the same as the polos pemade instrument which is played by hitting the same two notes, and there is also a game by closing the blade like a dong note that is crossed out with a "dot" sound. However, in pemade sangsih the strokes are not parallel or opposite to the beat of the melody gending, it is because pemade sangsih is an instrument that complements the empty space of the pemade polos instrument. So that both of them, when combined, can produce a harmonious tone.

Based on the description of the two types of playing techniques of the pemade instrument, it is clear that two systems are parallel or opposite to the melody beat between plain and sangsih strokes, but the 
two strokes still produce a balance of tones or a paired sound. These types of norot and oncang-oncangan strokes are applied to the technique of the Sekati Ririg Cenik gending playing where the norot strokes are played alternately with the oncang-oncangan strokes. So this really reflects the concept of balance in the dualism dimension because from the two strikes, there are significant differences, but both complement each other without leaving empty spaces.

Reyong / riong or some say riyong (Santosa, 2020) is an instrument in the gamelan Gong Kebyar which has several mon$\mathrm{col} /$ pencon as a sound source and is placed in one tungguhan which is an elongated shape. The reyong instrument's notes are twelve tones, including deng, dung, dang, ding, dong, deng, dung, dang, ding, dong, deng, dung. This instrument is played by four people in which each player has their own designation, including the striker (first player), pengenter (second player), penyelah (third player), and pemetit (fourth player). In the reyong instrument in the music of Sekati Ririg Cenik in Tejakula, several playing techniques can be found, namely slow norot (adeng) and fast norot (gencang). These techniques can be visualized through the musical notation as below.

\section{Slow Norot \\ Melody $\quad$............? \\ Peryorong : :0?0?0?0?0?0?220? \\ Pengenter $: 0 ? 0 ? 0 ? 0 ? 0 ? 0 ? 220$ ?}

Figure 4. The example of notation of slow norot (Adeng) playing technique in pemade instrument. (Doc. Aditya Putra, 2020)

Based on the musical notation related to the technique of playing the reyong instrument, this notation is only used to visualize the first (penyorog) and second (pengenter) players. The two games can represent the other two players.

The reyong instrument in the Sekati Ririg Cenik gending in terms of the playing technique shows that in the slow no- rot (adeng) playing technique it runs flat and at a slow tempo in accordance with the naming of the method itself. There is a ngempyung system in the game, namely simultaneously striking two different tones from the first reyong player (penyorog) to hit a dung tone while the second player (pengenter) strikes a ding tone.

Furthermore, in the fast norot playing technique (gencang) performed by the two players, both the striker stikes dang and ding tones and the pengenter strikes the dong and deng tones with a beat in medium or fast tempo from the slow norot technique that has been previously explained. So that this technique produces a one-tone direction, it is an emphasis on the dong tone. In accordance with the flow of the melody. From the naming of the technique and the relation of the two players, both of them reflect the dualism balance system; these two things remain in the series of gending presentations so as to produce a tone in accordance with the required melody, where both complement each other even though the playing system has differences.

\section{Quick Norot \\ Melody $\ldots+\ldots>\ldots ? \ldots$ \\ Peryorong

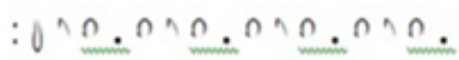 \\ Pengenter

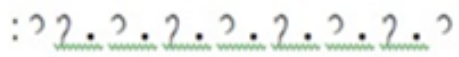

Figure 5. Example of the Quick Norot (gencang) playing technique notation on a pemade instrument (Doc. Aditya Putra,2020)

Furthermore, the trompong instrument, has a similar meaning to reyong. The trompong instrument at the Gong Kebyar barungan is also in the form of a pencon that is placed on an elongated tungguhan, but what distinguishes it from the previous reyong instruments is that the number of pencon in the trompong is ten notes. The intended tones' composition includes: dang, ding, dong, deng, dung, dang, ding, dong, deng, dung. This instrument is generally played by one player and is usually placed at the front in one barungan Gong 
Kebyar. The instrument (panggul) used in the trompong instrument has a shape and size that is bigger and longer than reyong, but both are played with both hands.

Talking about Sekati Ririg Cenik gending in Tejakula, the trompong instrument is played by three people in its presentation. The use of three players is that it actually gives a special characteristic in the presentation of the Sekati gending. According to what Pande Made Sukerta said, Sekati, especially in Tejakula, most clearly shows that Sekati gending, seen from the use of trompong instrument played by three people, as well as seen from the pattern of play on trompong instrument. This statement was also supported by Wirsutha, who said that three peoples played the trompong instrument. It struck a note according to the melody innocently without any variation called Sekati gending. The play only strikes notes one by one, which was Sekati's playing technique or katih (one) (interview on 12 July 2020). Based on some of the information about Sekati above, it can be understood that the protrusion of trompong instrument and the pattern of the play being struck by the three people are characteristic of Sekati's gending offerings in general, one of which is Sekati Ririg Cenik gending. It is so called because only Sekati gending in the presentation uses trompong instrument and is played as described Figure 6 .

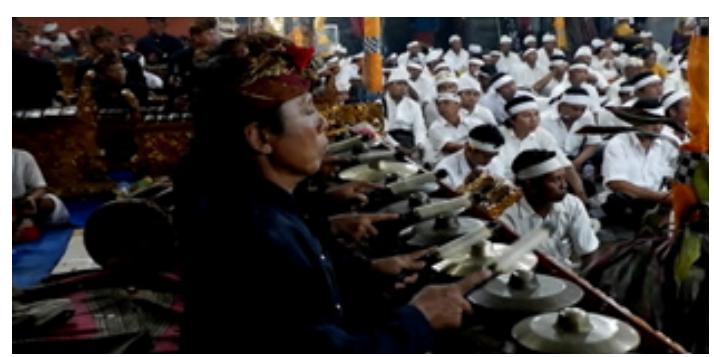

Figure 6. Trompong Instrument is played by three people in gending Sekati Ririg Cenik (Doc. Aditya Putra, 2018)

Based on the trompong game technique notation above, it can be seen that the three trompong players complement each other. The game forms a strand of notes according to the melody's groove, even though the three of them are indifferent tonal areas. The first player plays in the lowest note area, namely dang, ding, and dong, then the second player in the midpitch area includes deng, dung, and dang. The third player is in the lowest or highest area, namely ding, dong, hum, and dung notes. So, the three trompong players hit the tones according to their respective portions, and the combination of the three still creates a complementary balance.

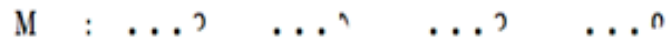

$$
\begin{aligned}
& \text { PI: . 100 3.0. ग. . . 30, } \\
& \text { PII : O..' I. I. I. I. D. } \\
& \text { PIII: } 27032.0 .2 .0 .20 \% 0
\end{aligned}
$$

Figure 7. Examples of playing technique notation on trompong (Doc. Aditya Putra, 2020)

Ceng-ceng Kopyak is also in Sekati Ririg Cenik gending presentation. Ceng-ceng kopyak is one of the instruments in the shape of a round disc with a diameter ranging from $21-25 \mathrm{~cm}$. The way to play it is by banging it with a partner so that it makes a sound. The instrument of ceng-ceng kopyak similar to acakep (cakupan) ceng-ceng consists of two discs of ceng-ceng in round shape. One player generally uses two discs ceng-ceng kopyak. Operationally, the existence of ceng-ceng kopyak in every barungan gamelan Gong Kebyar is not determined the number, There are at least three to six people who play it, so there are different patterns or techniques in the play. The striking technique of ceng-ceng kopyak is making a braided rhythm that produces Kekilitan (braid that is repeated simultaneously). Kekilitan ceng-ceng kopyak can be called "cek" and continue with the number of ceng-ceng kopyak strokes formulated by organizing its kekilitan. Ceng-ceng kopyak in the presentation of gending Sekati Ririg Cenik uses five-motif strokes technique. The description of ceng-ceng kopyak playing technique can be seen as Figure 8 . 


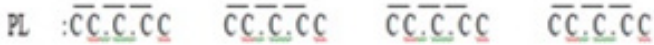

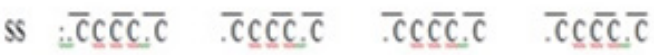

Figure 8. The example of playing technique notation in ceng-ceng kopyak instrument (Doc. Aditya Putra, 2020)

The example of the notation in Figure 8 indicates that the playing technique in ceng-ceng kopyak instrument also has the concept of dualism balance where gending presentation patterns or the strikes between polos and sangsih have different playing patterns. The polos stroke (PL) is played parallel to the beat while the sangsih stroke (SS) is against the beat, but the two strokes create a relation (cecandetan) or (kekilitan) which blends one player with their partner who is side by side. When one person only plays the play of ceng-ceng kopyak, the need for musicality relations will not be perfect.

\section{Tempo balance concept of Sekati Ririg Cenik Gending}

The tempo is a term from Italian, which literally means time, and in music, it denotes speed. Music can move at a certain speed, including very fast, medium, or slow, and music can be at various levels between them (Miller, 2017). Miller further explained three levels of tempo, including metronome, beats, Ritardando, and Accelerando. Sekati Ririg Cenik gending can be classified into the beats' tempo of the three tempo levels mentioned. It discusses two types of tempo, namely fast tempo and slow tempo. There are two types of repetition of the tempo in one series of songs / Sekati Ririg Cenik gending.

Starting from the beginning, of course, the presentation uses a slow tempo, then after approximately three times of gending rounds, the tempo is gradually faster marked or led by the kendang player. So that other instrument players can follow the course of gending being played. Furthermore, after performing several fast tempo gending rounds, Sekati Ririg Cenik gending tempo was returned to slow. To get the end of the gending, kendang instrument again adjusts the speed of the song gradually to a fast tempo and when it reaches the climax, Sekati Ririg cenik gending presentation ends with a slow tempo and a gong stroke.

Figure 9 is kendang instrument when setting the tempo in gending presentation Sekati Ririg Cenik. Setting the tempo in the presentation is very important to do because in addition to reducing the monotonous taste, these elements can also give soul or energy to the presentation. When fast tempo music/songs are sung, the resulting atmosphere indirectly gives a great impression. Meanwhile, when the song's tempo is slow, it can give a calm, soft and peaceful feeling. All that is not absolutely done depending on the agreement between each player presents Sekati Ririg Cenik gending. Therefore, it is clear that the concept of the dualism dimension is seen from the difference in the speed with which a piece is presented so that it can produce a balance.

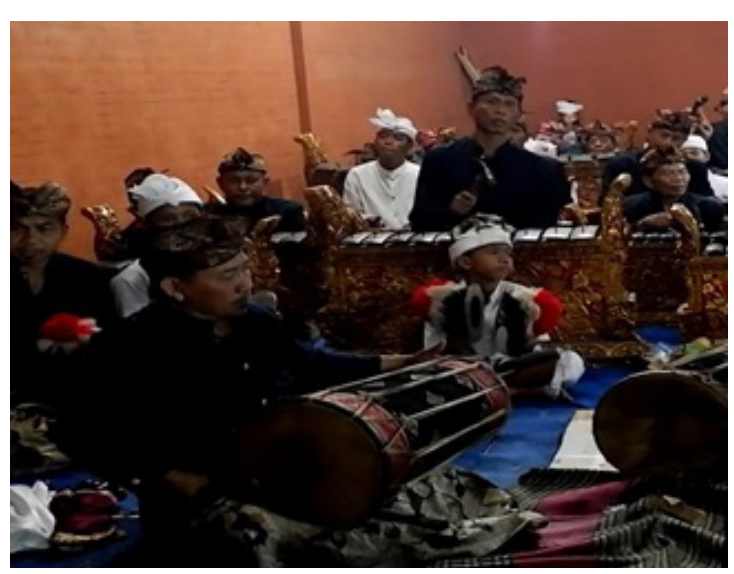

Figure 9. kendang instrument in setting the tempo (photo: Aditya Putra, 2018)

\section{Dynamic balance concept of Sekati ririg cenik gemding}

Furthermore, regarding the volume (dynamics) in music, according to Yasa (2016), the dynamics in the Gamelan Gender Wayang compared to Gamelan Gong Kebyar certainly have different dynamics regarding the volume (dynamics) in music. In the Gamelan Gender Wayang, of course, the device dynamics are softer, while the 
Gamelan Gong Kebyar has a louder level of device dynamics. Apart from that, the dynamics can also be viewed from the related gending. In line with Yasa's explanation above, when talking about dynamics, especially in Balinese gamelan, it is true when viewed physically and musically.

In general, Gamelan Gong Kebyar itself is known that every instrument has a dynamic set of sound or commonly known as ngumbang-ngisep. Rembang (1984) explains that ngumbang-ngisep sound in gamelan Bali is a ngombak sound system. The science of acoustics says that the sound of ngombak occurs due to a certain difference in frequency in one second from the source of the sound (tone) at the same time it is sounded. Ngumbang-ngisep shows the same two tones with a slight difference in tone frequency (high-low). The lower notes are called ngumbang, while the higher notes are called ngisep. The two tones are the same, and the slight difference in frequency, if you hit them together, will cause ombak. Besides, if observed from a musical perspective, the term ngumbang-ngisep can also be used in setting the loud dynamics of a song when played by a player simultaneously.

Based on the review above, that in every gamelan and musical composition concerned, when talking about a dynamic, it is clear that there is a very significant and predetermined difference. Likewise, Sekati Ririg Cenik gending presentation in the gamelan Gong Kebyar in Tejakula, of course, has a dynamic arrangement that has been determined in terms of the loudness of the musical presentation. The following is an example of setting dynamics in the presentation.

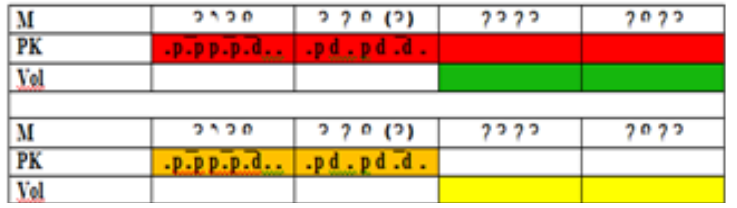

Figure 10. Example of dynamics setting on Sekati Ririg Cenik gending (Doc. Aditya Putra, 2020)
In Figure 10, the $\mathrm{M}$ symbol is a melody; the PK symbol is a drum stroke, namely p means pak and $\mathrm{d}$ means $d u g$, and the vol symbol is dynamics. In the dynamics setting on the Sekati Ririg Cenik gending presentation, the dynamics' loudness or softness is almost the same as the tempo setting above, which is set through the drums (kendang) instrument. On the red table is a sign of a drum stroke when it goes to the melody line of the gong's fall to adjust the loudness of the dynamic. So with this sign, then each instrument can improve the dynamics of the sound of its hitting, which is according to the green table. When you want to reduce the dynamic quality of the sound of all instruments to a low voice, the settings are the same when you want to improve sound dynamics, which can be seen in the orange table and the yellow table. The dynamic arrangement is not absolute; it means that it can change or be different according to the agreement between each player in the presentation one day at a different show.

In Sekati Ririg Cenik's repertoire, the dynamic usually begins with hard dynamics and then enters the comedian part or the gending content using soft dynamics. Furthermore, the dynamics led to the end of the repertoire, which again used hard dynamics and slowly ended with the dynamics becoming soft until the Sekati Ririg Cenik repertoire was finished. The setting of both loud and soft dynamics is also determined by the instrument's striking in the Gong Kebyar gamelan when the Sekati Ririg Cenik chant is presented. So, automatically, there is a concept of dualism that is different and can create a balance.

\section{CONCLUSION}

Based on the description above, it can be concluded that Sekati Ririg Cenik gending has the concept of a balanced dualism dimension in it. This concept can clearly be seen from polos-sangsih system in norot and oncang-oncangan playing techniques played on pemade and kantil instruments, the slow norot (adeng) and fast no- 
rot (gencang) playing techniques on reyong instrument, the trompong instrument that uses the technique of playing leluangan and tetorotan and ceng-ceng kopyak which form a relation with cek lima motif playing technique.

Apart from being seen from the plain-sangsih technique in the norot and oncang-oncangan playing techniques, the concept of balance can also be seen from the fast and slow tempo of a gending, loud and soft dynamics presented in the Sekati Ririg Cenik gending which uses gamelan Gong Kebyar by the people in the village. Customs of Tejakula, Buleleng Regency. Thus, it is clear that as a whole, what is mentioned above is also indirectly related to the dualism concept of life balance in the beliefs of the Hindu community in Bali which is called rwa bhineda.

\section{ACKNOWLEDGEMENT}

We express our deepest gratitude to RistekBRIN for providing financial assistance for the Master's Thesis research entitled "Gending Gamelan Sekati" and "Teknik Permainan Kendang Tunggal dalam Kajian Seni Karawitan Bali."

Thanks are also addressed to I Gde Arya Sugiartha, as the Rector of ISI Denpasar, the Chairperson of the LPPMPP ISI Denpasar and his staff, and all parties who have helped complete this research, which we cannot mention one by one.

\section{REFERENCES}

Aryasa, I. D. (1985). Pengetahuan Karawitan Bali. Departemen Pendidikan dan Kebudayaan Direktorat Jendral Kebudayaan Proyek Pengembangan Kesenian Bali.

Bandem, I. M. (1986). Prakempa Sebuah Lontar Gambelan Bali. ASTI Denpasar.

Bandem, I. M. (2013). Gamelan Bali di atas Panggung Sejarah. Badan Penerbit STIKOM Bali.

Diah, L. N. P. (2014). Eksistensi Tradisi Adat Ngoncang Di Desa Pegadungan, Kecamatan Sukasada, Kabu- paten Buleleng Ditinjau Dari Segi Nilai-Nilai Sosial Budaya. Pendidikan Kewarganegaraan Undiksha, 2.

Dibia, I. W. (2017). Kotekan Dalam Musik Dan Kehidupan Bali. Bali Mangsi Foundation dan ISI Denpasar.

Kriti, I. P. D. C. D. D. (2019). Bhaerawa Adalah Jalanku. Elex Media Komputindo.

Miller, H. M. (2017). Apresiasi Musik (Triyono Brahmantyo (ed.); Terjemahan). Thafa Media.

Mustika, P. G. D. (1996). Laporan Penelitian Mengenal Jenis-Jenis Pukulan Dalam Barungan Gamelan Gong Kebyar.

Putra, I. G. A. M. D. (2004). Panca Yadnya. Milik Pemerintah Provinsi Bali Kegiatan Peningkatan Sarana Prasarana Kehidupan Beragama.

Putra, I. K. A. (2019). Struktur Melodi Dan Gagebug Pada Gending Sekati Ririg Cenik Di Desa Adat Tejakula Kabupaten Buleleng. Kajian Seni, 06(1), 81-90.

Rembang, I. N. (1984). Sekelumit Cara-Cara Pembuatan Gamelan Bali. Departeman Pendidikan dan Kebudayaan Direktorat Jendral Kebudayaan Proyek Pengembangan Kesenian Bali.

Rismandika, K. A. (2018). Popularitas Gamelan Gong Kebyar Dalam Arena Pertarungan Kekuasaan Gamelan Bali. Selonding, 13.

Santosa, H. (2020). Critical Analysis On Historiography Of Gamelan Bebonangan In Bali. Paramita: Historical Studies Journal, 30(1), 98-107.

Sugiartha, I. G. A. (2015). Bentuk dan Konsep Estetik Musik Tradisonal Bali. Panggung, 25(1), 46-60.

Sugiyono. (2015). Metode Penelitian Kuantitatif, Kualitatif Dan RED. CV Alfabeta.

Sukerta, P. M. (2001). Jenis-Jenis Tungguhan Karawitan Bali. Proyek Pengembangan Media Kebudayaan Direktorat Jenderal Kebudayan Departemen Pendidikan Nasional Republik Indonesia.

Sutrisno, A. N. (2014). Telaah Filsafat Pendidikan. Deepublish. 
Utami, H. E. (2011). Kidung Sekaten Antara Religi Dan Ritus Sosial Budaya. Harmonia Jurnal Arts of Research and Education, 11(2), 153-162.

Utomo, U. (2006). Gender dan Musik: Kajian tentang Konstruksi Peran Lakilaki dan Perempuan dalam Proses Pendidikan Musik (Gender and Music: Research of Men's and Women's Role Construction in the Music Edu- cation Process ). Harmonia Jurnal Arts Of Research and Education, 7(1), 1-13.

Wadiyo. (2006). Seni Sebagai Sarana Interaksi Sosial (Art as a Tool of Social Interactions). Harmonia Jurnal Arts of Research and Education, 7(2).

Yasa, I. K. (2016). Aspek Musikologis Gender Wayang Dalam Karawitan Bali. Resital: Jurnal Seni Pertunjukan, 17(1), 46-59. 